\title{
Information Literacy in Class Culture-Based Learning
}

\author{
Ari Firmanto \\ University of Muhammadiyah Malang \\ ari@umm.ac.id \\ Moch. Irtadji \\ State University of Malang \\ moh.irtadji.fppsi@um.ac.id
}

\author{
I Nyoman Degeng Sudana \\ State University of Malang \\ nyoman.sudana.d.fip@um.ac.id \\ Tutut Chusniyah \\ State University of Malang \\ tutut.chusniyah.fppsi@um.ac.id
}

\begin{abstract}
A dynamic and very rapid change of time can only be followed by the mastery of information literacy. Students with high information literacy skills will understand information or materials given in the classroom more easily, and acquire knowledge more accurately. To obtain or develop information literacy competencies, it is necessary to establish a typical behavior in responding to the information. Students' involvement in the classroom can encourage them to behave better academically, be motivated, more curious in learning and be more enthusiastic in mastering the classroom materials. Classroom involvement is influenced by students' interest of the learning process (both in course materials and learning strategies), which has an impact on their learning achievement. Student and teacher collaboration in the classroom may also have an indirect effect on learning outcomes. Besides, class culture can increase the active participation of learners and encourage high-level thinking. Hence, the ability of positive and quality information literacy is influenced by how individuals are actively involved and able to practice the values they get in the classroom.
\end{abstract}

Keywords: information literacy, class culture, learning

\section{INTRODUCTION}

Information literacy is very important for all disciplines and an effective teaching and learning. Higher education institutions need to guide students and the lecturers in providing skills and tools to obtain information in various formats and media to identify, retrieve, and apply relevant and valid knowledge and sources of information for their studies, teaching, or research [1], [2]. However, previous studies found that many students had difficulty understanding the instructions in the textbook or developing their writing skills.

Low information literacy has triggered the spread of fake news [3], [4], thus having an information literacy skill becomes a need in order to develop one's ability, especially as a netizen, to deal with the spread of hate messages in the online domain, especially through social media [5]. Other studies also found that there was an effective increase in students' academic grades after they were given information literacy strengthening programs [6]. Teaching information literacy equips students with an anti-plagiarism attitude and encourages personal formation as an independent learner and prepares them to be a producer of information or knowledge based on ethics and scientific rules [7].

\section{INFORMATION LITERACY IN EDUCATION}

The learning process is the essence of implementing education in universities. The demands of society for efficiency, productivity, quality, effectiveness, and the usefulness of the teaching results in higher education are getting higher. However, there are usually some problems that hinder the success of the learning process, suh as low participation of students in the teaching and learning activities in the classroom [8], [9]. Many students tend to just sit, be quiet, and just listen to the lecture without giving any relevant response to the course materials.

During the lecture, there is hardly any questions or ideas related to the materials. It can be an obstacle that leads to the low student academic achievement. The low level of student participation in the classroom needs attention in order to find the cause and be overcome immediately. Some efforts to increase student participation in the classroom need to be made for the successful teaching and learning in all tertiary education [8], [10].

Among other possible factors influencing student classroom participation, learning motivation needs to be given special attention because low learning motivation seems to be the main contributing factor in the low level of student participation. Low learning motivation is related to the principles of learning, namely attention, relevance, confidence, and satisfaction [11], [12]. The attention of students in classroom learning is influenced by their interest in the learning process (both in lecture materials and learning strategies), while relevance shows the relationship between lecture materials, as well as students' prior experience or knowledge and needs [13]. Furthermore, student confidence must be cultivated and 
strengthened so the students can explore more in their learning journey. It is when the learning process takes place in accordance with the students' interests, characteristics, and needs, then the learning satisfaction can be achieved [14].

To foster students learning motivation and increase their participation, learning must be creatively designed to promote interaction, negotiation and construction of meaning, so that meaningful learning will be achieved [15]-[17]. Creative and meaningful learning design becomes important because even though learning is a universal process, but in reality, it occurs in a particular cultural community and learning outcomes will be applied to certain cultural communities as well. In this case, the use of local culture in learning is beneficial in designing creative learning to produce contextual and meaningful learning. In other words, the learning process in the classroom must use a cultural approach, namely by linking the lecture material with the concepts that come from the local culture where students come from [18], [19].

Through developing the concept of local culture in the learning process, it will be easier for students to understand the materials. Indeed, one of the best ways to increase student participation in learning is by using a culture-based learning approach. Bashar; Harris; Panebianco [20]-[22] explained that a culture-based learning approach can provide opportunities for students to create meaning and achieve an integrated understanding of the scientific information obtained, as well as the application of scientific information in the context of the cultural community problems.

\section{CULTURAL ASPECTS IN CLASSROOM LEARNING}

The situation of the classroom often impacts on the student attitudes or behavior in learning. If the classroom atmosphere is positive / conducive, students will display better academic behavior, be positive, motivated, more curious in learning and be more encouraged to understand the learning materials [23], [24]. This shows that the class culture greatly impacts on the student academic behavior.

Cultural aspects in the classroom should be reflected in the school curriculum, policy, teaching methods and teacher communication patterns. These aspects will build students' cognitive skills that are integrated in their learning behavior and improve their academic achievement [25], [26]. The ability of students to master the materials is usually influenced by the classroom situation. The classroom learning settings can influence how students develop their patterns of understanding and obtaining information as an effort to gain knowledge [27].

Classroom learning is carried out with a variety of methods, which is selected and designed by the teacher to set certain learning goals [28]. Some external factors including class culture play an important role in the learning atmosphere where students will develop more positive values and other academic behaviors.
Class culture is manifested in the interaction between teachers and students. Educative interaction is an interaction that takes place for educational and teaching purposes. Educative interaction is actually reciprocal communication between one party and another with certain intentions, namely to achieve goals in learning activities [21], [29], [30]. An interaction is considered educative if consciously has a purpose to educate and deliver students towards their maturity. Communication activities for human beings are an essential part of their lives. However, not all forms and activities of interaction in a life take place in an atmosphere of educative interaction, which is designed for a particular purpose. Interactions are created in the classroom with various interaction models, which are able to support student learning outcomes that meet the learning objectives [31], [32].

(Behavioral) culture is a pattern / system created in the form of attitudes, values, behavioral norms, language, beliefs, and rituals, which are formed, developed and passed on to group members as the personality of the group that distinguishes them from other groups and determines how groups feel, think and react to diverse environments and function to overcome internal and external adaptation problems [33]. Culture is a concept that moves through a continuum, starting from cognition and beliefs about other people and oneself, including values and patterns of behavior. Customs and activities are part of cultural norms, namely behavioral models that have been recognized and required [34].

Cultural behavior in the classroom is a collective system, beliefs, basic assumptions, values, language, boundaries, norms, ideology, myths and rituals that are taught to students as a way to see, think, feel, behave, and expect others to behave in their group. The values and beliefs of a class lead to a series of organized actions, including activities in a classroom that are usually rooted in class values. This activity is strengthened by the dominant values and beliefs [35], [36].

By adopting Denison's cultural model, it can be explained that there are four dimensions of organizational culture, namely involvement, consistency, adaptability and mission [37]. Dimensions in classroom culture (adaptation of Denison's Model) include involvement, consistency, adaptability and mission.

First, involvement is a treatment that makes all members of the group feel included in the group activities so as to make them accountable for their actions. Involvement is freedom or independence that each individual has in expressing his opinions. It needs to be appreciated by the group as long as the idea is to advance and develop the group.

Secondly, consistency is the level of group members' agreement on the basic assumptions and core values of the group. It emphasizes the belief systems, values, and symbols understood and shared by the members as well as the implementation of coordinated activities. The consistency is marked by the ties between group members. In this case, the boundary between do's and 
don'ts is clear. This dimension maintains strength and stability in the classroom.

Thirdly, adaptability is the ability of students to interpret the influence of the environment on the class. This ability is related to the ability to respond to changes in the external environment by making internal group changes with the aim of developing and growing the class.

The last dimension in classroom culture is mission. It shows the core objectives of the group that make students stay firm and focus on what is considered important by the class. Inability to do the mission will result in students not understanding the expected results and the unclarity of the long-term goals.

Culture-based learning is the creation of a learning environment and the design of a learning experience that integrates culture as part of the process of gaining an understanding that there are scientific rules in daily life in its cultural community, and there is also a culture in the context of the field of science to be able to obtain integrated understanding and scientific skills in perceiving something around it [36]. Culture-based learning allows a change in learning culture from teacher centered to student-focused learning [14], [32].

\section{CLASS CULTURE-BASED LEARNING IMPROVES INFORMATION LITERACY SKILLS}

Classroom is the most important mean in the implementation of the learning process in school. Hence, it is suggested that the education personnel consists of professionals who have high motivation. In other words, the teacher must be professional in "handling" classes for the implementation of an effective and efficient learning process [38]. Classroom atmosphere influences the attitudes or behavior of students in learning. If the classroom atmosphere is positive / conducive, students will display better academic behavior, be positive, motivated, more curious in learning and be more encouraged to understand the learning materials [23], [24].

Cultural aspects in the classroom should be reflected in the school curriculum, policy, teaching methods and teacher communication patterns. These aspects will build students' cognitive skills that are integrated in their learning behavior and improve their academic achievement [25], [26]. The ability of students to master the materials is usually influenced by the classroom situation. The classroom learning settings can influence how students develop their patterns of understanding and obtaining information as an effort to gain knowledge [27].

Teacher learning strategies will encourage all students to explore more about the learning resources. Classroom learning is carried out with a variety of methods, which is selected and designed by the teacher to set certain learning goals [28]. In acquiring the knowledge, students should not be dependent solely on teachers and textbooks. Students should be able to independently find the information they need. Thus, giving assignments to students can stimulate and increase students' creativity, develop their independence, provide confidence, foster students' habits to always seek and process information, make students more passionate in learning, and create responsibility and discipline [32].

Classroom learning attitudes and student behavior influence teacher expectations and students' attitudes and behavior. Also, attitudes and behavior of students and teachers towards class collaboration and interaction have an indirect effect on learning outcomes [35]. Class culture produces effective learning behavior and is applicable to a variety of learning conditions or learning materials, which has an impact on improving students' achievement [39].

Student information literacy skill is not only influenced by the level of students' intelligence, but also their ability to regulate their learning methods well and efficiently [40], [41]. Individuals are able to find appropriate and efficient learning strategies, gain knowledge from the sources used, and motivate themselves to continue to understand the materials being studied [42]. Individuals make causal attribution to help realize their own successes and failures, thus developing a sense of desire to improve their ability to overcome the challenges of information literacy in the future [43].

Cultural aspects in the classroom should be reflected in the school curriculum, policy, teaching methods and teacher communication patterns. These aspects will build students' cognitive skills that are integrated in their learning behavior and improve their academic achievement [25], [26]. The ability of students to master the materials is usually influenced by the classroom situation. The classroom learning settings can influence how students develop their patterns of understanding and obtaining information as an effort to gain knowledge [27]. If the classroom atmosphere is positive / conducive, students will display better academic behavior, be positive, motivated, more curious in learning and be more encouraged to understand the learning materials [23], [24]. Clearly, class culture has an impact on the student academic behavior.

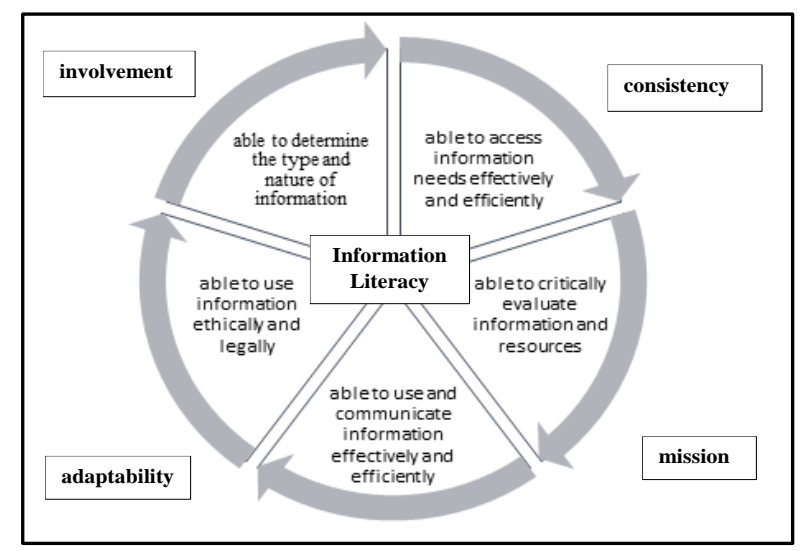

Figure 1: Information Literacy in class culture 


\section{CONCLUSION}

Class culture-based learning is an integrative activity that includes the development of learning relationships, the realization and structuring of class community structures that respect each other, productive learning activities in meaningful curricula, moral development, decision making regarding instructional time and objectives, as well as the increase in students' motivation and involvement in the education process. Class-oriented learning encourages students to develop their abilities in finding information.

Class culture creates effective learning behavior and is applicable to various learning conditions or learning materials, which has an impact on improving students' achievement. Students acquire and develop information literacy competencies through an in-depth learning process and from various important learning sources in a dynamic environment. Besides, there is a cognitive process in which students apply new and past information to plan, as well as create new information and utilize it efficiently and ethically.

\section{REFERENCES}

[1] J. Defazio, J. Jones, F. Tennant, and S. A. Hook, "Academic Literacy: The Importance and Impact of Writing across the Curriculum-A Case Study," J. Scholarsh. Teach. Learn., vol. 10, no. 2, pp. 34-47, 2010.

[2] J. Elander, K. Harrington, L. Norton, H. Robinson, and P. Reddy, "Complex skills and academic writing: a review of evidence about the types of learning required to meet core assessment criteria," Assess. Eval. High. Educ., vol. 31, no. 1, pp. 71-90, 2006.

[3] Kominfo.go.id, "Rendahnya literasi digital jadi penyebab penyebaran berita hoax," 2017.

[Online]. Available: https://kominfo.go.id/content/detail/8806/rendah nya-literasi-digital-jadi-penyebab-penyebaranberita-hoax/0/sorotan_media.

[4] vokasi.ui.ac.id, "Universitas Indonesia Gelar Workshop 'Tangkal Hoax Melalui Literasi Informasi Kesehatan,”’ 2017. [Online]. Available: http://vokasi.ui.ac.id/web/universitasindonesia-gelar-workshop-tangkal-hoaxkesehatan/.

[5] V. Juliswara, "Mengembangkan model literasi media yang berkebhinekaan dalam menganalisis informasi berita palsu (hoax) di media sosial," $J$. Pemikir. Sosiol., vol. 4, no. 2, pp. 142-164, 2017.

[6] A. Syamsi, "Penguatan literasi informasi berbasis perpustakaan bagi peningkatan mutu akademik mahasiswa Pgmi Iain Cirebon," J. Pendidik. Sekol. Dasar, vol. 2, no. 2, pp. 24-37, 2016.

[7] D. Boden and S. Holloway, "Learning about plagiarism through information literacy: a fusion of subject and information management teaching at Imperial College London'," in Proceedings of the JISC Plagiarism: Prevention, Practice and Policies Conference, 2004.

[8] E. S. Anderson and T. Z. Keith, "A longitudinal test of a model of academic success for at-risk high school students," J. Educ. Res., vol. 90, no. 5, pp. 259-268, 1997.

[9] J. L. Berger, C. Girardet, C. Vaudroz, and M. Crahay, "Teaching Experience, Teachers' Beliefs, and Self-Reported Classroom Management Practices: A Coherent Network," SAGE Open, vol. 8, no. 1, pp. 1-12, 2018.

[10] P. D. Rishi Sriram, "Rethinking Intelligence: The Role of Mindset in Promoting Success for Academically High-Risk Students," J. Coll. Student Retent. Res. Theory Pract., vol. 15, no. 4, pp. 515-536, 2014.

[11] C. P. Schmidt, "Relations among Motivation, Performance Achievement, and Music Experience Variables in Secondary Instrumental Music Students," J. Res. Music Educ., vol. 53, no. 2, pp. 134-147, 2005.

[12] G. Hampden-Thompson and J. Bennett, "Science Teaching and Learning Activities and Students' Engagement in Science," Int. J. Sci. Educ., vol. 35, no. 8, pp. 1325-1343, 2013.

[13] Alexander, Psychology in learning and instruction. Upper Saddle River. N.J: Prentice Hall, 2006.

[14] S. E. Quay and R. J. Quaglia, "Creating a Classroom Culture that Inspires Student Learning," Teach. Profr., vol. 18, no. 2, pp. 1-5, 2004.

[15] E. Keogh, F. W. Bond, and P. E. Flaxman, "Improving academic performance and mental health through a stress management intervention: outcomes and mediators of change.," Behav. Res. Ther., vol. 44, no. 3, pp. 339-57, Mar. 2006.

[16] K. S. Ostrow, "Enhancing Student Motivation and Learning within Adaptive Tutors," in The 8th International Conference on Educational Data Mining, 2015, pp. 668-670.

[17] A. J. Martin, "Enhancing student motivation and engagement: The eVects of a multidimensional intervention $\square$," Contemp. Educ. Psychol., vol. 33, pp. 239-269, 2008.

[18] M. Larsson, "Exploring a framework for classroom culture: A case study of the interaction patterns in mathematical whole-class discussions," in Proceedings of the Ninth Congress of the European Society for Research in Mathematics Education, 2015, pp. 3065-3071.

[19] L. F. Zhang, "University students' learning approaches in three cultures: an investigation of Biggs's 3P model.," J. Psychol., vol. 134, no. 1, pp. 37-55, 2000.

[20] B. Harris, Creating a Classroom Culture That Supports the Common Core. New York: Routledge, 2014.

[21] M. K. Bashar, "Classroom Culture and Its Importance in the Post Methods Era for 
Designing Pedagogy in Bangladesh," Int. J. African Asian Stud., vol. 26, pp. 89-95, 2016.

[22] J. Panebianco, "Managing Classroom Culture : Classroom Demographic Shift Affects Teacher Preparedness," Purdue J. Serv. Int. Engagem., vol. 1, no. 1, pp. 31-32, 2014.

[23] C. O. Walker, B. A. Greene, and R. A. Mansell, "Identification with academics, intrinsic/extrinsic motivation, and self-efficacy as predictors of cognitive engagement," Learn. Individ. Differ., vol. 16, pp. 1-12, 2006.

[24] S. A. Gauci, A. M. Dantas, D. A. Williams, and R. E. Kemm, "Promoting student-centered active learning in lectures with a personal response system," Adv. Physiol. Educ., vol. 33, pp. 60-71, 2009.

[25] V. Purcell-Gates, "Epistemological tensions in reading research and a vision for the future," Read. Res. Q., vol. 47, no. 4, pp. 465-471, 2012.

[26] C. Kiili, M. Mäkinen, and J. Coiro, "Rethinking Academic Literacies," J. Adolesc. adult Lit., vol. 57, pp. 223-232, 2013.

[27] N. Mercer and C. Howe, "Explaining the dialogic processes of teaching and learning: The value and potential of sociocultural theory," Learn. Cult. Soc. Interact., vol. 1, pp. 12-21, 2012.

[28] D. J. Short, J. Echevarría, and C. Richards-Tutor, "Research on academic literacy development in sheltered instruction classrooms," Lang. Teach. Res., vol. 15, no. 3, pp. 363-380, 2011.

[29] L. B. Gambrell, "Creating Classroom Cultures That Foster Reading Motivation," Read. Teach., vol. 50, no. 1, pp. 14-25, 1996.

[30] M. Pohl, "Developing a Classroom Culture of Thinking: A Whole School Approach," TEACH J. Christ. Educ., vol. 5, no. 1, pp. 8-9, 2012.

[31] S. Pati, K. Hashim, B. Brown, A. G. Fiks, and C. B. Forrest, "Early identification of young children at risk for poor academic achievement: preliminary development of a parent-report prediction tool," BMC Health Serv. Res., vol. 11, no. 1, p. 197, 2011.

[32] T. Altun, "Exploring the Effects of Classroom Culture on Primary Pre-Service Teachers, Professional Development," Aust. J. Teach.
Educ., vol. 38, no. 9, pp. 37-54, 2013.

[33] Y. Y. Kim, Becoming Intercultural: An Integrative Theory of Communication and CrossCultural Adaptation. SAGE Publications, Inc., 2001.

[34] C. H. Dodd, Dynamics of intercultural communication. McGraw-Hill, 1997.

[35] R. F. Cavanagh and R. F. Waugh, "Secondary school renewal: The effect of classroom learning culture on educational outcomes," Learn. Environ. Res., vol. 7, no. 3, pp. 245-269, 2004.

[36] N. Kojima, "The Importance of Understanding Students ' First Classroom Culture," Polyglossia, vol. 23, pp. 15-20, 2012.

[37] D. R. Denison, S. Haaland, and P. Goelzer, "Corporate culture and organizational effectiveness: is there a similar pattern around the world?," in Advances in Global Leadership (Advances in Global Leadership, Volume 3, Emerald Group Publishing Limited, 2003, pp. 205-227.

[38] J. Brophy, "Educating teachers about managing classroom and students. Teacher and Teacher Education," An Int. J. Res. Stud., vol. 4, no. 1, pp. 1-18, 1988.

[39] M.-D. Lozano, "Investigating task design, classroom culture and mathematics learning: an enactivist approach," ZDM Math. Educ., vol. 49, no. 6, pp. 895-907, 2017.

[40] P. R. Pintrich and E. V. De Groot, "Motivational and self-regulated learning components of classroom academics performance," J. Educ. Psychol., vol. 82, no. 1, pp. 33-40, 1990.

[41] P. R. Pintrich, "A conceptual framework for assessing motivation and self-regulated learning in college students," Educ. Psychol. Rev., vol. 16, pp. 385-407, 2004.

[42] R. Vollmeyer and F. Rheinberg, "Motivational effects on self-regulated learning with different tasks," Educ. Psychol. Rev., vol. 18, no. 239253, 2006.

[43] S. Charubusp and A. Chinwonno, "Developing Academic and Content Area Literacy: The Thai EFL Context," Read. Matrix, vol. 14, no. 2, pp. 119-134, 2014. 